\title{
The Implementation Of Brand Standards In Franchised Retailing: The Field Of Car Dealerships
}

\author{
Benjamin Morisse, ESSCA School of Management, LUNAM University, France
}

\begin{abstract}
The management of franchised retailing networks often involves the implementation of brand standards throughout the dealership. However, these standards might not be met, whether because of the dealer's management of its own assets or because of the customer contact staff's behavior towards clients. This article analyses the dissonance between the brand's prescribed standards and staff behavior across retailers for the field of car retailing. It offers management recommendations designed to bring staff behavior closer in alignment with brands' knowledge.
\end{abstract}

Keywords: Franchised Retail; Brand Standards; Deviations; Specifications; Effectiveness; Incentives; Control; Automotive

\section{INTRODUCTION}

\section{Research aim: Brand standards' implementation}

\section{c} $\mathrm{n}$ franchised retailing settings, implementing brand standards constitutes a critical management concern across retail networks. Management teams thus have designed facilitation and control tools to serve as both incentives and prescriptions for dealers. For example, granting dealers management knowledge and tools should increase the level of control in the franchised retail sector, including over behaviors and the type and organization of the tangible and intangible assets held by dealers. This structuration often prompts reactance among retailers though, in that they are reluctant to adopt brand standards and prefer to assert their independent company status.

\section{Initial assumptions of the paper: the staff's reluctance to implement trustfully the brand standards}

The abovementioned clash constitutes a classic management issue between the theoretical methods for prescriptive control and the reality of asset management, from the perspective of the dealers that are responsible for reproducing the brand's delivery scenario and ensuring service quality. This addresses some issues in terms of customer satisfaction for brands whose dealers are distributed all over a territory and have to comply with brand standards. That is, the delivery scenario, as originally designed for the overall network, often gets altered in its actual implementation by customer front-line employees in franchised retail locations. For managers, the key is to understand, and thereby address or eliminate, the reasons for this distortion of brand knowledge in the implementation stage.

\section{Reasoning for the focus of the paper}

This paper proposes a possible means to address this conflict, in which we consider the implementation of franchised retailing assets from the perspective of service marketing research and its insights into process implementation. In turn, these developments are contrasted with the reality of car retailing practices, which rely on specific systems of franchised dealers. 


\section{Research objectives}

The main objectives are to identify the causes of deviation from the brand standards at the dealership's level and the incentives making possible that the behaviors comply with the standards.

To gain insights into these real-world practices, we examine the results from a field study of various automotive dealer networks.

With these data, we then propose a classification of the incentive practices of retail networks and match them with the forms of compliance exhibited by dealers.

Our analysis ultimately leads to several management recommendations, designed to control the distortions between standards and implementation in a network.

\section{Originality of the paper and contribution to knowledge}

This paper aims at renewing the approach linking retailing management and customer satisfaction. This approach was earlier focused in the field of salesforce management (Haji-Basri, 2012). The assumption is that customer satisfaction can be the objective of every front-desk staff (Aburoub and alii, 2011), whatever is his/her mission. The paper also challenges the mainstream idea - for franchised businesses are concerned - that discretion (ie. more freedom in action or decision) among employees at organization's lower levels could improve their performance (Caza, 2011). Another originality of the paper to be pointed out is the field study. It consists in the case studies of five brands dealers' networks, in the car sector. These have been completed by an immersive approach through participant involvement of the author in regular interactions with managers of the car sector.

The theoretical frame supporting the implementation of brand standards in a franchising format will be presented in a first section. Then, the methodology and the results of the field study conducted in the car sector will be detailed in a second one.

\section{ASSET IMPLEMENTATION IN FRANCHISED DEALERSHIPS}

When products demand heavy manufacturing processes and lifelong technical maintenance, but sell in uncertain markets, they tend to push the retail function to independent dealers, as exemplified by the automotive sector since the 1920s (Sloan, 1963).

\section{Prescriptions, Reality, and Dealers’ Deviations}

In franchise relationships (Williamson, 1996), the brand represents the main asset. It attracts clients, using tangible signals of its presence (e.g., store design, technical facilities), and promises a certain level of behavioral standards by the staff members who represent the brand, whether as brand employees or as representatives (e.g., dealers' employees wearing brand emblems while performing after-sales services). The brand as an asset also can attract private investors. To live up to these promises, the brand and its retail network need common behaviors and codes. According to Hodgson (1998), cultural conflicts instead engender dissonance between practices and the cognitive frameworks used by various network agents. Franchised dealer networks offer a promising way to share brand culture, across the car manufacturers and the market participants, without endangering the industry's flexibility.

A similar phenomenon arises when service efficiency depends on a shared organizational culture, interpersonal and technical skills, and strong knowledge of products and services (Schneider \& Bowen, 1984). Yet in this case, franchised dealer networks can suffer management challenges, because service performance is evaluated not just on easily measurable criteria but also through informal skills (e.g., team relationships) that are difficult to codify or transfer to individual employees.

Because management practices strongly emphasise adherence to and control of brand standards, to ensure behavioral compliance with the company's general policies (Ogenyi, 1998), car manufacturers and dealers invest 
resources to ensure reporting of and rewards for standards compliance (De Horatius and al., 2007). For example, in February 2011, the Volkswagen Group created a global position for its Chief Executive Compliance Officer, responsible for monitoring compliance with the company's mission statement and the behaviors of stakeholders in the value chain. Such efforts to monitor dealers' compliance with brand standards seek to bring the reality in line with the prescriptive ideals (Sarin and al., 2012).

The service marketing distinction between emerging deviations and deliberate deviations appears apt in this case (Lovelock \& Wirtz, 2010). The former arise from business contingencies that cause people to carry out situation-driven adjustments, which may diverge from the prescriptions. The latter instead result from measures designed to accomplish the mission. Regardless of their type, all deviations mean that practices have moved away from prescriptions, which may threaten the fulfillment of the promise made to customers (Wilson and al., 2008), such that any deviation requires managerial monitoring to limit their scope and negative effects. A management trend appeared in the late 1990s / early 2000s which consisted in supporting discretion among employees, especially at lower levels in the organizations. This was largely inspired by the Japanese philosophy of quality and implemented through empowerment practices. It supposed to entrust employees with more freedom in their actions or decisions. In terms of customer satisfaction, empirical evidence has not proven the discretion's efficiency (Caza, 2011).

\section{Incentive and Control Tools}

To ensure fit between reality and prescriptions, franchised retail networks usually rely on incentive tools that attract private investors who will represent their brand effectively, together with control tools that seek to harmonize field practices and curb opportunistic behaviors by delegated representatives (Coase, 1988). First, incentive tools include investment support (e.g., for premises, equipment), which encourage compliance with brand standards; bonuses awarded for reaching or bettering volume targets or inventory costs; joint promotional operations; financial tools designed to facilitate dealers' cash management; and bonuses awarded for scores on customer satisfaction indexes. Car manufacturers use these incentive tools to attract dealers to represent them; dealers in turn should be likely to comply with the brand standards shared across their network (De Horatius and al., 2007). To encourage its dealers to support heightened standards for the Lincoln brand, the Ford Group has paid an extra bonus of \$50-\$75 per vehicle sale since January 2011 (LaReau, 2011).

Second, control tools correlate with incentive tools. Franchised retail networks usually rely on a field organization, whose purpose is to support dealers and ensure that their tangible and intangible asset management complies with the delivery scenario inscribed in the brand standards. This organization includes (with varying terminology) area or region inspectors or managers that are responsible for promoting dealers and controlling their activity. The scope of their operations encompasses both trade and management control. To implement retail knowledge, they provide dealers with necessary reporting tools (e.g., management charts, integrated sales management tools, invoicing terms). These tools both facilitate dealership management and produce homogeneous information about how it functions. This type of interference by network heads in the day-to-day management of dealers' business even has led to legal proceedings, based on the concept of de facto management practices. In that perspective, dealers claimed that carmakers were improperly interfering in their business, in that they constrained the main business decisions (such as investment, staff and facility management). Some analysts characterized this under the "hierarchy inside the market" phenomenon.

\section{One Form of Control: Mystery Shopping}

Customer responsiveness offers another method for ensuring compliance with brand standards, usually measured by surveys, though also through the increasingly prominent practice of mystery shopping. Notable research into this practice has proposed methods for evaluating product offering quality (Morrison, Colman, \& Preston, 1997), assessing customer satisfaction (Divard, 2009; Wilson, 2001), and managing front-line employees through assistance and training regarding their specific mission and, more broadly, that of the dealership (Finn, 2001). 
In parallel with their search for efficiency in manufacturing, many companies have sought to generalize a so-called lean retailing model (Kniebihler and al., 1998, Kalta and al, 2001), which controls downstream network costs by focusing on the flows of products and related services. To implement this model, car manufacturers have promoted dealer groups, which facilitate their regionally driven business practices. In turn, many dealers have grown in size, and thus in market power. From an economic perspective, their greater market power increased dealers' ability to comply with brand standards; from a management perspective though, it fostered more strategic autonomy, which has threatened brand standard compliance. Some dealers have self-organized their tangible and intangible assets to improve their own efficiency, such that they might pit brands from the same group against one another or diversify their activity into other business lines. The Belgian D'Ieteren Group has diversified its vehicle retail activities to include short-term car rentals (by buying Avis Europe) and car glass repair (by buying 93\% of the Belron Group, which also owns the Carglass brand). However, some of these massive car dealer groups also suffer from unfavorable fixed cost structures, which helped bring about the mass bankruptcies during the 2008-2009 economic crisis. The European giant Kroymans, a dealer group that once had sold 80,000 new vehicles annually, vanished from the motor trade in 2010. Some car manufacturers appear to be limiting the number of contracts they enter into with the same dealer, to avoid their (often local) dependence on the bigger dealers. With a moderate size, it becomes possible to choose investors with the capacity to make investments in brand representation but still ensure entrepreneurial vitality by having the investor in the business.

\section{FIELD TESTING BRAND STANDARDS IN CAR DEALERSHIPS}

\section{Methodology}

The qualitative approach adopted in this paper to determine the managerial reality of brand standards' implementation by sales and after-sales service staff stems from case studies carried out through action research.

\section{Case Study Research Method and Unit of Analysis}

The choice of case study was formerly considered as appropriate for the preliminary stages of an investigation, making use of phenomenological approaches (Bourdieu, 1977) and ethnography or anthropology (Giddens, 1984). The use of these studies in various fields of marketing like advertising, store design, consumer behavior or product development (Prior and al., 2012) brought acknowledgment of the scientific value of this methodology. It is nowadays accepted to test hypotheses or build theories from practices through case studies (Flyvberg, 2006), as inductive methodologies do. Case studies can also be appropriate for assessing the prevalence of former theories at the light of their predictability in a "real life" context. Learning about the "in action" (Giddens, 1984) has appeared adequate regarding the issue of the paper, which questions the implementation of brand standards at the level of retail store. Considering the abovementioned statements, the "in action" of the front-line staff seemed relevant to be investigated, which appeared compatible with building on formerly developed knowledge in service marketing.

The unit of analysis is the car dealership, where do operate many staffs, in sales and aftersales businesses. These will be described in the next section.

\section{Selection of cases, determination of data gathering and analysis techniques}

This field study has selected five cases in respect of the "information-oriented selection-maximum variation cases" Flyvberg's(2006) typology. This means that selected cases bring understanding about the significance of various phenomena, processes or outcomes. In that perspective, cases have to be very dissimilar.

To gather a sample that would provide an accurate portrait of the contemporary automotive retail sector in the European market, this study includes three main types of companies: independent single-brand dealers, dealer groups, and brand subsidiaries. The brands involved represented more than $70 \%$ of the sales' mix of the French market in which the study took place, including all three French brands (Citroën, Peugeot, and Renault), one premium imported brand (BMW), and one imported brand (Seat, Volkswagen Group). We summarize the interviewed populations in Table 1; all employees thus represented sales or sales management and after-sales positions. 
These two service employee groups adopt different professional cultures, and though both interact with clients, the interactions take place in specific situations that engender different consumer expectations. Customer satisfaction and its criteria differ, depending on whether consumers buy a vehicle or need maintenance services. The two employee groups also undergo different customer relations training programs. Sales staff usually attend sales training programs, and their performance measures focus on sales indicators. In contrast, only recently have aftersales service staff, whose skills are primarily technical, been invited to expand the business aspects of their mission. This difference in professional cultures should influence the respondents' awareness and implementation of brand standards.

Table 1. Study participants

\begin{tabular}{|l|c|c|c|c|c|c|}
\hline \multirow{2}{*}{$\begin{array}{c}\text { Brand } \\
\text { Network }\end{array}$} & \multicolumn{3}{|c|}{ Sales Sector } & \multicolumn{3}{c|}{ After-Sales Sector } \\
\cline { 2 - 7 } & Dealer & Sales manager & Sales assistant & $\begin{array}{c}\text { After-sales } \\
\text { manager }\end{array}$ & $\begin{array}{c}\text { Receiving agent } \\
\text { spare parts and } \\
\text { accessories }\end{array}$ \\
\hline Citroën & 2 & 1 & & & & 1 \\
\hline Peugeot & 1 & 1 & & 1 & & 1 \\
\hline Renault & 3 & 1 & & & 1 & \\
\hline Seat & 3 & & 1 & & & 1 \\
\hline BMW & 2 & & & & 2 & \\
\hline
\end{tabular}

To supplement this population, we interviewed sector experts, professional senior executives in the sector, and employees of an automotive brand network head. These six supplementary interviews supported triangulation of the information collected from the main respondents. Specifically, they included four representatives from the French automotive services Union (ANFA-GNFA), including training consultants and trainers regularly involved in training regarding brand standards, and two representatives from regional offices (Citroën and Renault). The interview guide is available in the Appendix.

The analysis techniques of the cases are anchored in ethnography and action research. Action research is appropriate for research or consultancy tasks associated with contingent problem solving. Initially based on methods developed in twentieth century ethnographic research (Lewin, 1946), action research promotes the importance of the context. The methods used in action research have grown more homogeneous, enabling users to structure even piecemeal or scattered data. Thus, action research has been adopted to work together with participant observation (Whyte, 1991), reflective thinking (Revans, 1978), and data triangulation (Glaser \& Strauss, 1967). In the field of marketing, Arnould and Wallendorf (1994) promoted the immersive approach through participant involvement, accepting the risk of bias resulting from the researcher's own preconceived notions (Diamond, 1996).

\section{Evaluation and analysis of the data}

In an exploratory phase, interviews took place between March and May 2007, conducted by two welltrained research assistants, and then were entirely transcribed. Content analysis served to assess the information. With the verbatim transcriptions, we could reconstruct the reality that the interviews revealed, as related to the appropriation of or deviations from brand standards, by classifying the information provided into principal themes that reflected managerial reality. The longitudinal data collection spans multiple networks; any language bias was mitigated by regular cross-checks against the supplementary field observation sessions.

The next step consisted in an immersion phase (the abovementioned "participant involvement") in the automotive retail sector, in which we interacted on a regular basis with senior executives in the motor trade. The main advantage of this phase was that it supports triangulation the narratives previously collected. These interactions took place during a period in which the executives and the author were designing and then delivering an in-company management training program. The immersion process gave us access to internal documents that summarized the manufacturer's brand standards; such documents are usually not publicized, because of the confidential information they contain. Finally, in weekly meetings with head office brand representatives and bi-monthly meetings with branch managers, we gained a fuller understanding of the dealers' thoughts, which represents the most downstream link of the value chain. This phase also supported fuller triangulation of the data. This overall second phase lasted one year, from January 2008 and January 2009. 


\section{Findings in accordance with the theoretical framework and initial assumptions}

This presentation of findings follows the pattern set in the first section, namely, dealing first with the tangible and intangible assets of the automotive retail sector, then with the observation of incentive and control tools.

\section{Tangible and intangible asset management}

- $\quad$ Retailers' knowledge of standards

Of the 24 total people interviewed, only 2 stated that they lacked knowledge about their brand standards, yet their knowledge gap was balanced by their vast professional experience. Thus, in response to the question, "Do you apply those standards in your day-to-day business?" one premium brand dealer answered: "No, not really. But ... I use it because I know how it works. I've been in retail for 30 years, eventually one does know a little...." Among those respondents who knew the standards, their attitudes toward implementation largely reflected a feeling of obligation or deliberate behavioral intentions based on free consent (Caza, 2011). For example, to a question relating to perceptions of standards, "What do you think of these procedures? How do you see them?" a premium brand receiving agent answered, "It's good! Good thing they exist, precisely because for [the brand], they target the customer. So, we have to do what they say. If they decide to target a particular type of client, we have to work like this."

\section{- $\quad$ Deviation from brand standards}

When standards get altered, the reasons for the deviation are situation-specific or else reflect a deliberate attempt to question the validity of the standard. One after-sales director asserted, "I want to talk about a specific item in the standard, it's client mobility, that is, automatically offering a courtesy car. Unfortunately, we don't have spare vehicles for all our clients; we've got about 30 after sales appointments a day and we can't afford to have 30 cars to lend customers every day."

\section{Incentive and control tools}

In-field implementations of brand standards depends on retailers' appropriate knowledge of the related incentive and control tools.

\section{- $\quad$ Brand networks vs. private networks}

At the company level, tangible and intangible assets management choices are strongly influenced by carmakers' recommendations; whether choices are left to the facilities, suppliers, or service providers; the training program applied; and the presence of an employee pay-plan policy. Disparate situations emerged, depending on whether they pertained to a franchised dealer or a dealership, which was a wholly owned subsidiary of the manufacturer. Employed executives, whose task is to ensure the faithful implementation of the brand standards, manage carmakers' factory-owned dealerships. For example, the training program for the dealership managers of a manufacturer did not include any cash management modules. Factory-owned dealerships also are required to enter into contracts whose terms would be unacceptable to private dealers. The required method to handle calls for tender in public administrations offers a case in point: These contracts generate high volume vehicle sales, subject to pricing conditions that are unfavorable to retailers, and they include buy-back provisions at the end of the contract. Most private investors lack adequate funding to absorb such a massive volume of vehicles at the contract term's end.

The demographic disparity across dealerships (i.e., numbers of employees and record of sold vehicles) can partly explain the varying ability of dealers to implement practices that deviate from brand standards. For example, in response to an item related to the carmaker's audit of brand standards, one sales manager explained what amounted to an internal preliminary practice: "[We have] two audits a year: the real audit [the brand] grades us on, and a pre-audit internal to the Group; in other words [I will audit] another Group's dealership ... regarding the standards, and they will come here and pre-audit us before the [car manufacturer's] real audit." This type of practice is available only to dealers that are big enough to enable this kind of guidance though. 
- $\quad$ Brand standards confronting new dealer groups

The recent history of the automotive retail sector has been marked by reduced cultural gaps between carmakers' structures and the structures of increasingly large dealers. In some cases, dealer groups grow even larger (in terms of units of cars sold, across all brands, and employees) than the car manufacturer or import company they represent. Moreover, the cost of stand-alone management tools is substantial enough that only really large dealer groups can afford to develop standards that deviate from those of their manufacturers, such as possessing their own customer relationship management (CRM) system or central spare parts purchasing office.

In terms of personnel behavior, brand standard implementation strongly correlates with the management of the dealership that employs them. Although standards adherence does not directly affect them ("The dealership is remunerated. People are not incented. There's another pay-plan system, based on something else. On sales, on results, on goals that are reached"), staff gets incited to comply with the standards by their own managers, who receive regular feedback from the systematic customer satisfaction index and reports from mystery clients, sent one to six times a year.

\section{- $\quad$ Mystery clients}

The interviews and close collaboration observations revealed that mystery shopping practices in the automotive retail sector are better established among brands that target a high-end positioning than among generalist manufacturers that boast important sales volumes and high returns in their client satisfaction surveys. It also creates perceptions of control, according to one dealer of a German brand: "First, they send mystery clients to see whether we're doing our job. At one point, we got neurotic about this mystery client ... we started thinking, 'Is it him, should I go further?'... So that's the main fear: Did I make it? And that can bring pressure."

\section{Standards deviation}

The practices revealed in terms of standard deviations fit readily into an existing service marketing classification: If a situation does not lend itself to by-the-book standards implementation, deviations emerge. As one dealer commented, "In fact, it all depends on the client. There are things that they ask ... for instance, to talk about the after-sales service. If this is an existing customer, this section gets reduced because he knows. We'll repeat the same things 25 times ... and he'll notice." In other circumstances though, mainly in the after-sales business, teams regard the standards as hindrances on the success of their mission, so they deliberately depart from them. An aftersales receiving agent explained, "When we receive a vehicle or a client, we should ... in theory go over the vehicle from top to bottom and spend 15 minutes per client. The problem is that if we've got five clients in front of us and we spend 15 minutes per client, one of them is going to wait one hour and a quarter. You can't always do everything, but then they're aware of this."

Overall this investigation reveals three main leverage tools that facilitate the implementation of standards in the automotive retail sector:

- $\quad$ Economic incentives that network heads put in place to incite dealers to manage their assets in accordance with standards.

- $\quad$ Dealership managers, who relay the prescribed practices to their teams and ensure proper understanding of the standards.

- Interactions with clients, whose behavior in the service delivery may facilitate or hinder implementation of a specific standard.

\section{CONCLUSION: CLASSIFICATION OF INCENTIVE AND CONTROL TOOLS AND MANAGERIAL RECOMMENDATIONS}

To describe the implementation of brand standards in the automotive retail sector, this article summarizes the behavior of dealers, in terms of standards compliance, and the management methods used by retail network heads (whether of manufacturers or import subsidiaries, depending on the markets involved), in Table 2. The 
classification leads into several managerial recommendations for retail network heads, designed to provide answers to the initial problem of reducing the gap between prescriptions and reality.

\section{Classification of Practices}

The field survey of five brands, commentaries from specialists about other brands, and insights from running a management training program for a car manufacturer in combination led to the identification of nine specific situations.

Table 2. Synthetic classification of practices

\begin{tabular}{|l|l|l|l|l|}
\multicolumn{2}{c|}{} & \multicolumn{3}{c|}{ Retail Network Head's Behavior } \\
\cline { 3 - 5 } & $\begin{array}{l}\text { Barely prescriptive } \\
\text { brand standards }\end{array}$ & $\begin{array}{l}\text { Strong controls, } \\
\text { weak incentives }\end{array}$ & $\begin{array}{l}\text { Strong incentives, } \\
\text { strong controls }\end{array}$ \\
\hline $\begin{array}{l}\text { Strict } \\
\text { implementation of } \\
\text { standards }\end{array}$ & $\begin{array}{l}\text { Brands newly } \\
\text { established in a } \\
\text { market; network } \\
\text { development }\end{array}$ & $\begin{array}{l}\text { Brands with high } \\
\text { sales volumes }\end{array}$ & $\begin{array}{l}\text { Brands with high } \\
\text { added value, limited } \\
\text { volumes (e.g., } \\
\text { BMW) }\end{array}$ \\
\cline { 2 - 5 } & Emerging deviations & $\begin{array}{l}\text { Unstable network; } \\
\text { management depends } \\
\text { on the catchment area }\end{array}$ & $\begin{array}{l}\text { Brands with high } \\
\text { growth potential; } \\
\text { dense territory } \\
\text { representation }\end{array}$ & $\begin{array}{l}\text { Brands with high } \\
\text { growth potential, } \\
\text { represented by retail } \\
\text { groups }\end{array}$ \\
\cline { 2 - 5 } & Deliberate deviations & $\begin{array}{l}\text { Brand in unfavorable } \\
\text { situation in its market }\end{array}$ & $\begin{array}{l}\text { Dealer group } \\
\text { dominating a } \\
\text { particular area }\end{array}$ & $\begin{array}{l}\text { Dealer group } \\
\text { diversifying }\end{array}$ \\
\hline
\end{tabular}

\section{Practical implications}

In each scenario identified in Table 2, retail network heads need to make appropriate choices between incentives and control, in line with their competitive position, to achieve the best dealer network configuration.

- $\quad$ First, for the barely prescriptive standards, strict implementation scenario, managers should increase the types of incentives offered, to expand the network and attract new dealers. This option is particularly appropriate for new brands in a specific market (e.g., Korean and Chinese brands in Europe).

- $\quad$ Second, when there are strong controls, weak incentives, and strict implementation, brands can guarantee their dealers high sales volumes, so they can achieve an adequate return on capital invested in a network organization that enforces compliance with brand recommendations. In particular, improving dealers' reporting and proximity management tools can help ensure homogeneous representation for these widely distributed brands.

- $\quad$ Third, the situation marked by strong incentives, strong controls, and strict implementation occurs mainly among narrowly distributed brands, with a positioning that demands high quality retail standards. In return, dealers receive financial incentives to comply, as is the case for German brands such as BMW, Mercedes, or Volkswagen, whose annual compliance-related bonuses may reach $\$ 180.000 / € 150,000$ for an averagesized sales area. The mystery client method and regular interviews of clients should serve to monitor standards compliance, and the incentives need to be sufficiently attractive to draw dealers that will make considerable investments in representing the brand well and earn their basic income on the returns on those investments. As an illustration, the average investment needed to build a dealership for the three mentioned German brands is about $€ 5$ million in Europe (real estate plus sales and after-sales facilities).

- $\quad$ Fourth, with barely prescriptive standards and emerging deviations, the brand management of the network is difficult; prescriptions reflect the market power of the dealer in that area. It could be the result of a compromise by brands that seek to operate in a market but that lack the sales volume to develop control tools, which are comparatively more expensive than laissez-faire methods.

- $\quad$ Fifth, the strong controls, weak incentives, and emerging deviations scenario is characteristic of brands with high growth potential, which are densely represented in the territory. Controls relate more to management processes than to operations, as exemplified by brand networks for Ford or GM, which mainly target huge business operations. In this situation, the findings from this article recommend developing tools 
for commercial reporting and sharing know-how about the basics of financial management (e.g., cash resources, working capital requirements, stock rotation) to guide the flow of products. It requires network management that is more tactical than concerned with respect for brand positioning.

- Sixth, though similar to the previous scenario, the situation marked by strong incentives, strong controls, and emerging deviations pertains instead to large retail groups for which, because of the volumes of units sold, manufacturers strengthen their controls to avoid threatening their brand representations in the local areas. To contain deviations, manufacturers could benefit from developing bonuses directly linked to standards compliance that are easy to implement.

- $\quad$ Seventh, when the situation features barely prescriptive standards and deliberate deviations, it implies that the brand has declined in the market, and management can no longer control dealers. This situation might arise if the product plan is poorly adapted or corresponds to a niche, and the network can no longer recoup its investment. Therefore, the brand must accept the dealers' behavior to preserve its representation; in extreme situations, it even might have to accept multi-branding with other brands in the same showroom, even if this positioning is not necessarily the one it seeks. For non-European readers, this situation is quite unusual since multibranding is strictly regulated by the European Commission. For instance, a multibrand dealer has to dedicate specific assets to every retailed brand in its business (specific showroom and aftersales facilities per brand).

- $\quad$ Eighth, strong controls, weak incentives, and deliberate deviations occur when a brand confronts a retail group that dominates a particular area and that is likely to subvert the brand standards to impose its own standards or increase its business volumes. For example, a retail group operating on the west coast of France has chosen to create its own central sourcing office to purchase spare parts straight from parts manufacturers, rather than from the brand. In such a situation, the findings of this study recommend encouraging the installation of new dealers in the area, to challenge the deviant dealer's dominant position. The purpose of current European regulations is to foster such intra-brand competition within networks.

- $\quad$ Ninth and finally, the strong incentives, strong controls, and deliberate deviations situation appears in very large dealer groups (sales of more than 10,000 vehicles/year). The situation requires a high degree of service delivery integration and internal management processes, which are both highly structured and brand-independent (i.e., separate CRM, management control, human resources information systems) and have sufficient market power to cause brands to accept the arrangements. Although the manufacturers' market power is unfavorable, they need to pursue these relationships, because evidence has shown that these dealers are most likely to achieve standard compliance through their regular investments. Moreover, their size enables them to achieve greater business volumes, which is valuable in heavy industry contexts, such as automotive manufacturing, that constantly seek economies of scale.

\section{Further research and limitations}

Most management conflicts found in the contemporary automotive retail sector appear to stem from an organizational pattern that has remained unchanged since the 1920s. At the time of its implementation, it corresponded to an input balance, whereby manufacturers provided management knowledge to dealers, which in turn provided mainly after-sales service, without many managerial skills. The increasing size of dealers and the emergence of independent management processes have radically altered this characteristic. Further research therefore should address ways to increase brand attractiveness for retail investors assessing their returns on investment.

The main limitation of the paper stems from the intrinsic methodology of case studies, whose ability to generalization and predictability can be characterized as limited. However, as stated by Giddens (1982), the purpose of case studies is not to be predictive but rather to understand given phenomena. The purpose of understanding the phenomenon of implementing brand standards at the scale of car dealerships has remained constant throughout this research.

\section{AUTHOR INFORMATION}

Benjamin Morisse, holds a PhD in Management Science from the University of Caen (IAE) and is tenured Professor of Marketing at ESSCA, where he has been successively Professor and Chair of Automotive Retail and 
Services, Dean of the Faculty, and Vice-Dean. He is also a visiting professor at the WFI of the Catholic University of Ingolstadt (Germany), where he conducts an annual seminar on Automotive Issues in Business Science. His research pertains to manufacturer-dealer relations in a franchised retailing context. E-mail: benjamin.morisse@essca.fr

\section{REFERENCES}

1. Aburoub A.S., Hersh A.M., Aladwan K. (2011), Relationship Between Internal Marketing and Service Quality with Customer's Satisfaction, International Journal of Marketing Studies, Vol 3, 2, May, 107-118.

2. Arnould, E. \& Wallendorf, M . (1994) Market-oriented ethnography: interpretation building and marketing strategy formulation, Journal of Marketing Research, 31, 4, 484-504 .

3. Baron S., Harris K., Davies B. (1996), Oral Participation in Retail Service Delivery : a Comparison of the Roles of Contact Personnel and Customers, European Journal of Marketing, 30, 9, 75-89.

4. $\quad$ Bourdieu, P. (1977). Outline of a theory of practice. Cambridge, UK: Cambridge University Press.

5. Campbell, D. T. (1975). Degrees of freedom and the case study. Comparative Political Studies, 8(1), 178191.

6. Caza A. (2011), Testing Alternate Predictions for the Performance Consequences of Middle Managers' Discretion, Human Resource Management, January-February, 50, 1, 9-28.

7. Coase, R.H. (1988), The firm, the market and the law. Chicago: University of Chicago Press.

8. De Horatius N., Raman A. (2007), Store Manager Incentive Design and Retail Performance: an exploratory Investigation, Manufacturing and Service Operations Management, 9, 4, fall, 518-534.

9. Diamond, J. (1996). The roots of radicalism. The New York Review of Books, November 14, 4-6.

10. Divard, R. (2009), Les enquêtes mystère, une technique délicate à mettre en œuvre. Décisions Marketing, 53 (janvier-mars), 31-42.

11. Finn, A. (2001), Mystery shopper benchmarking of durable goods chains and stores. Journal of Service Research, 34 (May), 310-320.

12. Flyvberg B. (2006), Five Misunderstandings about Case Study Research, Qualitative Inquiry, 12, 2, April, 219-245.

13. Giddens, A. (1982). Profiles and critiques in social theory. Berkeley: University of California Press.

14. Giddens, A. (1984). The constitution of society: Outline of the theory of structuration. Cambridge, UK: Polity Press.

15. Glaser, B.G. \& Strauss, A.L. (1967), The discovery of grounded theory. Chicago, Aldine.

16. Hodgson, G. (1998), Competence and contract in the theory of the firm. Journal of Economic Behavior and Organization, 35, 179-201.

17. Haji-Ba sri M. (2012), Marketing Research Contemporary Themes and Trends, Interdisciplinary Journal of Contemporary Research in Business, September, 12, 17-24.

18. Kalta M., Kleiner B. (2001), Managing Dealerships Effectively, Management Research Review, 2001, 24, 3/4, 22-28.

19. Kniebihler, M. \& Giaoui, F. (1998), L'Automobile sans concession. Paris, Editions d'organisation.

20. LaReau J. (2011, February 14), Ford imposes standards on Lincoln dealers. Automotive News, p. 18.

21. Lewin K. (1946), Action research and minority problems. Journal of Social Issues, 2, 34-46.

22. Lovelock, C. \& Wirtz, J. (2010), Services marketing: people, technology, strategy, 7th ed. Englewood Cliffs, NJ: Prentice Hall.

23. Morrison, L., Colman, A. \& Preston, C. (1997), Mystery customer research: cognitive processes affecting accuracy. Journal of the Market Research Society, 39 (April), 349-361.

24. Ogenyi, E.O. (1998), Franchising agreements in new car retailing: an empirical investigation. Service Industries Journal, 18 (2), 144-160.

25. Prior D.D., Miller L. M. (2012), Webethnography, Towards a Typology for Quality in Research Design, International Journal of Market Research, 54, 4, 503-520.

26. Revans, R.W. (1978), Action learning and the nature of knowledge/learning. Education and Training, 19, 318-320.

27. Sarin S., Chagalla G., Kohli A. (2012), Implementing Changes in Marketing Strategy : the role of Perceived Outcome and Process-oriented Supervisory Actions, Journal of Marketing Research, XLIX, Aug, 564-580. 
28. Schneider, B. \& Bowen, D. (1984), New services design, development and implementation and the employee. In George, W. \& Marshall, C. (eds.), Developing new services. Chicago: AMA Proceedings Series, 27-43.

29. Sloan, A.P. (1963), My years with General Motors. New York: Currency Doubleday (1990 edition).

30. Whyte W. (ed.) (1991), Participatory action research. London: Sage.

31. Williamson, O.E. (1996), The mechanisms of governance. Oxford: Oxford University Press.

32. Wilson A. (2001), Mystery shopping: using deception to measure service performance. Psychology \& Marketing, 18 (July), 721-734.

33. Wilson, A., Zeithaml, V., Bitner, M., \& Gremler, D. (2008), Services marketing. New York: McGraw-Hill. 


\section{APPENDIX. INTERVIEW GUIDE}

\section{Knowledge}

"Do you know the brand standards relating to receiving customers?"

"Could you name a few of them?"

\section{Retail/communications about welcome standards}

"How were you informed of these standards?"

"Do you have any documents on brand standards?"

\section{Behavior intentions}

"Do you try to apply those standards on a daily basis when you welcome clients?"

\section{Attitude}

"What is your opinion of these standards?"

"Is this what you think of all standards?"

\section{Perceived control}

"Is it easy for you to implement these standards on a daily basis?"

"Are some standards more constraining than others?"

\section{Feeling of obligation}

"Do you feel that you have to implement these standards?"

"Does your manager make you feel that it is important to implement these standards?"

"What do you gain by putting these standards into practice?"

\section{Deviations}

"Are there situations where standards cannot be applied?"

"Do you customize welcome standards to the situation?"

\section{Operational invariants}

"According to you, which items of information are essential and must be considered when welcoming customers?" "What do you pay attention to?"

"Apart from the standards, what knowledge base do you use to receive clients properly?"

"Have you worked out your own reception strategy?"

"Have you set your own rules and principles?"

"What makes your way of receiving clients different from that of a colleague?" 